\begin{tabular}{|c|c|c|c|}
\hline $\begin{array}{l}\text { A CaSe } \\
\text { Study }\end{array}$ & $\begin{array}{r}\text { ADVANCE RESEARCH JOURNAL OI } \\
\text { Volume } 5 \mid \text { Issue } 2 \mid \text { December, } 2014 \mid 242-244\end{array}$ & F SOCIAL SCIENCE & \\
\hline $0=$ & DOI: 10.15740/HAS/ARJSS/5.2/242-244 & Visit us : www.researchjournal.co.in & \\
\hline
\end{tabular}

\title{
Role of tribal farm women in decision making towards agricultural operations
}

Pratiksha Singotiya*, N.K. Khare and Sonam Agrawal Jawaharlal Nehru Krishi Vishwa Vidyalaya, JABALPUR (M.P.) INDIA

\section{ARTICLE INFO :}

Received : 10.10 .2014

Accepted : 25.11.2014

\section{KEY WORDS :}

Tribal farm women, Decision making, Agriculture operation

\section{HOW TO CITE THIS ARTICLE :}

Singotiya, Pratiksha, Khare, N.K. and Agrawal, Sonam (2014). Role of tribal farm women in decision making towards agricultural operations, Adv. Res. J. Soc. Sci., 5 (2) : 242-244.

*Author for correspondence

\begin{abstract}
The women are the backbone of agricultural workforce but worldwide her hard work has mostly been unpaid. She does the most tedious and back-breaking tasks in agriculture, animal husbandry and homes. They undertake various activities in agriculture such as field preparation, sowing, intercultural practices, weeding, harvesting, picking, grains cleaning, grains storage etc. In this study tribal farm women take the decision making process in eight agriculture operation like crop selection, seed selection, seed treatment, use of weedicide, use of fertilizers, plant protection measures, improved method of storage, time of selling farm produce etc. Hence, the present study was conducted to determine the contribution of tribal farm women in decision making mainly in crop selection. The study that total of 105 tribal farm women were selected as respondents from each five villages of selected block. Related data were collected with the help of personal interview technique. Data analysis by appropriate statistical tools. Whereas, found that recessive in decision regarding farm operation like seed treatment, use of weedicide and plant protection measure etc. Because it is note that most of decision was dominated by male. It is necessary that encourage of tribal farm women for development of his family by appropriate decision and it is a task for government, policy makers and for all to empower the tribal farm women from each and everywhere.
\end{abstract}

